\title{
Positioning the Testimony of Job Ben Solomon, An Enslaved African American Muslim
}

\author{
Muna Sulaiman Al-Badaai \\ English Literature Department, United Arab Emirates University \\ P. O. Box 15551, Al-Ain, United Arab Emirates \\ E-mail: munasn@uaeu.ac.ae
}

Received: 20-04- 2015

Accepted: 25-07- 2015

Advance Access Published: August 2015

Published: 01-11- 2015

doi:10.7575/aiac.ijalel.v.4n.6p.204 URL: http://dx.doi.org/10.7575/aiac.ijalel.v.4n.6p.204

\begin{abstract}
Ayyub Ben Suleiman Diallo, better known as Job ben Solomon was among thousands of African Muslims enslaved in America. Job was a son of a high Priest from Senegal. He was kidnapped by his African enemy and sold as a slave in the New World in 1731. He worked on a tobacco plantation in Maryland. He ran away and was captured and imprisoned. Job's literacy in Arabic attracted the attention of the philanthropist James Oglethorpe who helped to free him. In 1733, Job sailed to England and later returned to Africa. Upon Job's request, Thomas Bluett wrote Some Memoirs of the Life of Job the Son of Solomon (1734). Allan Austin claims in his book African Muslims in Antebellum America: Transatlantic Stories and Spiritual Struggles (1997) that Job might be considered as the "father of African American Literature". Muhammad Al-Ahari (2006) states that this account "is perhaps the earliest biography of any African-Americans". However, William Andrews (1988) with other scholars consider the year of 1760 the appearance of slave narrative as genre. What is more, African Muslim slave narratives have been excluded from African American anthologies. Florence Marfo (2009) in her article entitled "African Muslims in African American Literature" discusses some possible reasons for this omission which mostly relate to the perceived identity of enslaved African American Muslims and the absence of an anti-slavery goal in their narratives. This paper aims to position Job's testimony in the light of arguments made by the other scholars.
\end{abstract}

Keywords: antebellum, Ayyub, canonization, enslaved Muslims, Job Ben Solomon, slave narrative

\section{Introduction: Job's Testimony and Slave Narrative Criticism}

Marion Starling states "the slave narrative records extend from 1703 to 1944" (p. xviii) and the first slave narrative was Adam Negro's Tryall (p. 50). However, Briton Hammon's A Narrative of the Most Uncommon Sufferings and Surprizing Deliverance of Briton Hammon, a Negro Man, which was published in 1760, has been treated as the primary slave narrative. Kenith Green (2014) comments that Hammon's narrative "has been recognized as the first slave narrative published in North America" (p. 101). Then, Green in his article's endnotes elaborates the argument of the first slave narrative. His note remarks that most scholars, such as Philp Gould, William Andrews and Rifia Calls, believe that Hammon's narrative as the earliest account, except Starling who remarks that Adam Negro's Tryall (1703), "the court record of a New England slave's freedom suit against his master, John Saffin", as the first slave narrative (p. 119).

Some Memoirs of the Life of Job the Son of Solomon, the High Priest of Boonda in Africa; Who was a Slave About Two Years in Maryland; and Afterwards Being Brought to England, was Set Free, and Sent to His Native Land in the Year (1734) was written by a European man, Thomas Bluett (Note i), and before the American independence. Despite these two facts, Allan Austin (1997) considers Job the "father of African American Literature" (p. 51) and Muhammad AlAhari (2006) includes the narrative among "Muslim slave narratives" and states that the testimony "is perhaps the earliest biography of any African-Americans" (p. 12). Al-Ahari adds that the account "was definitely the first slave narrative offered by sale through advertising in a newspaper" (2006, p. 12). Vincent Carretta (2010) discusses the problem in the usage of the term of "African American" to describe eighteenth-century writers who were writing prior to the independence of the United States: those who were against the American Revolution (i.e. Black Loyalists); those who chose to live and die outside the U.S, like Equiano and Gronniosaw. Therefore, according to his argument, Job ben Solomon and his account should not be called African American (p.11). Arguably, this is the same reason for why Starling does not discuss Job's testimony in her study.

In the same vein, Florence Marfo's article “African Muslims in African American Literature” (2009) attempts to investigate the possible reasons that led "commentators on African American literature" to exclude the early narratives of enslaved Muslims from anthologies of African American literature (p. 1213). One of these reasons is the possibility that a work was written by a western writer. This can lead to the claim that the narrative is not authentic enough and consequently does not convey the genuine emotions of a slave because the writer is not an enslaved person himself. Marfo cites as an example Some Memoirs of the Life of Job. However, many narratives by enslaved and ex-enslaved 
African Americans were not written by them. For instance, Ukawsaw Gronniosaw's narrative was not written by Gronniosaw himself as its title shows, rather it was "committed to paper by the elegant pen of a young LADY of the town of LEOMINSTER" (2000, p. 3). What is more, the issue of authenticity and authorship has been questioned even concerning well-known self-authored narratives, such as by Olaudah Equiano, Solomon Northup and enslaved narrators.

These arguments regarding the authenticity of slave narratives, nationality and identity of enslaved African American Muslims have been frequently questioned (Noteii). For instance, in fact all African American Muslim slave narratives were written by those who were African-born. Questions emerge here regarding these narratives whether they should be considered as other African American slave narratives or should be described as a sub-genre as Paul Lovejoy (2011) suggests that the narratives of African-born enslaved people would be better named as 'freedom narratives' (p. 93). AlAhari (2006) believes that African American Muslim slave writings "can be called the true beginnings of American Islamic English Literature" (p. 12). Perhaps, however, the phrase "slave writings" would be a more accurate description of enslaved Muslim writings. The suitable descriptive term can be found through analyzing and comparing these narratives to African American slave narratives. However, African American Muslim slave writings were not discussed deeply (Note iii) in some primary studies in African American slave narratives and their characteristics, such as Andrews's To Tell a Free Story: The First Century of Afro-American Autobiography, 1760-1865 (1988) and Foster's study Witnessing Slavery (1994) of the development of slave narrative (Note iv). Again considering the characteristics of African American Muslim slave writings and comparing them to conventions of African American slave narrative, all this can provide a more comprehensive picture about the particular position of Job's testimony, which is the focal aim of this article.

\section{General Characteristics of Early Slave Narrative (Proto-slave Narrative)}

Starling (1981) states that "the slave narrative records ... are to be discovered in judicial records, broadsides, private printings, abolitionist newspapers and volumes, scholarly journals, church records, unpublished collections and a few regular publications" (p. xvii). Besides, Hammon, other widely discussed eighteenth-century slave narrators are James Albert, or Ukawsaw Gronniosaw (1770), John Marrant (1785) and Olaudah Equiano, or Gustavus Vassa (1791). Even though 1760 has been considered as the year of emergence of the of slave narrative genre, there is not a firm definition of early slave narratives. In his article "Back to the Future: Eighteenth-Century Transatlantic Black Authors", Carretta (2010) presents how hard it is to give a definite definition of the eighteenth-century slave narratives because of their complexity. He discusses Hammon's, Gronniosaw's, Marrant's, and David George's (1791), Venture Smith's (1798) and Equiano's narrative. Generally, early slave narratives are called spiritual autobiographies, biographies, conversion narratives, captivity narratives, slave narratives, or confession narratives. Regarding Equiano's narratives, Carretta claims that his narrative is "a remarkable achievement, it is very difficult, if not impossible, to classify in terms of its genre. Among other things, it is a spiritual autobiography, captivity narrative, travel book, adventure tale, rags-to-riches saga, economic treatise, apologia, testimony, and slave narrative" (p. 17). Likewise, in chapter two "Voices of the First Fifty Years, 1760-1810", Andrews (1988) describes some early African slave writings as spiritual autobiographies, criminal confessions, and slave narratives.

Regarding the structure of eighteenth and nineteenth-century slave narratives, they start with a preface or a letter which was written by a respected European or American person. The purpose of these remarks was to vouch for the authenticity of the account and morality of the ex-enslaved narrator. Commonly, early slave narratives follow a chronological order and use straightforward and accessible language in order to "amuse its readers while encouraging them in their humanitarian and religious efforts (Foster, 1994, p. 45).

The anti-slavery argument in early slave narratives is not always clear or direct. They aimed to show themes of morality, equality and justice. Possibly, focusing on these themes was a result of the prevailing religious perspective (Notev) which was perhaps the main themes in early slave narratives. Carretta (2010) discusses the historical background of the religious movement the Great Awakening in the 1730s, a "transatlantic evangelical Christian movement", originating in England, and its influences in eighteenth-century slave narratives (p. 13). Foster (1994) describes that:

Eighteenth-century slave narratives emphasized the individual, and for the most part they reflected the Puritan theocentric society. Race was a factor in the narrator's manner and matter, but it was not at first a crucial element. Their emphasis was upon a theme more easily identified with all heirs to Judeo-Christian philosophy, the struggle for existence as strangers in an inhospitable land. (p. 44)

Religion also affected the style of early slave narratives. Early slave narrators quoted from the Holy Bible. Hammon's narrative is a religious autobiography. Gronniosaw's narrative also serves as a good example which discusses how his enslavement was the way to obtain his religious identity, a Christian. The narrator developed throughout the narrative especially spiritually, personally and intellectually. Starling Bland (2001) states that early slave narratives have religious components, whereas nineteenth-century slave narratives appear to be more political to reveal the anti-slavery theme even though some narratives continued to present the religious perspective.

A significant concept in the eighteenth-century slave narrative is that the slave narrator illustrates the idea of the "noble savage". The slave or ex-slave appears to be educated and to behave in a refined manner especially those who came from a high social class in their land of origin. The late seventeenth-century fiction novel, Oroonoko (1688) by Aphra 
Behn strongly presents the "noble savage" theme. Foster, Andrews, Philip Curtin (1967) and Safet Dabovic (2009) as well as Werner Sollors (2001) in his introduction to Equiano's narrative, all draw attention towards the idea of the noble savage and slave narrators. For example, Foster in this context states that "the savage but noble concept that was so popular in eighteenth-century racial thought could explain the eighteenth-century narratives' predilection for highborn African narrators" (1994, p. 46).

Commonly, the plots of eighteenth-century slave narratives, as Foster states start with an exposition- "with accounts of the slave life before captivity". Rising actions are about an enslaved person's kidnapping, captivity and his life in slavery and accompanying ill-treatment. "The narratives climaxes with [the captives'] rescue from slavery and a spiritual or material reward for the hardships encountered" (1994). Generally, early slave narratives as a genre do not have a fixed definition. Typically through religious perspectives, these narratives discuss the themes of equality and justice more than the anti-slavery theme. In a chronological order, the plots trace the enslaved narrators' lives from before their enslavement to the moment of obtaining freedom and convey their spiritual and intellectual development over the course of the narratives. The question that arises here is to what extent the characteristics or traditions of Job's testimony share the general characteristics of early slave narrative.

\section{Analysis and Characteristics of Job's Testimony}

Job asked Bluett to write down his account which consists of a letter, an introduction, four sections and a conclusion. In the letter, Job requested Bluett "to write an Account of him" (Notevi) to the Duke of Montague "as an Acknowledgment of your GRACE's great Humanity and Goodness" to Job (as cited in Austin, 1984, p. 75). The letter, as Austin (1997) states, is an "obligatory flattering dedication to the Duke" (p.53). The letter conveys the motivation of writing this account. This can suggest that the narrative does not carry an antislavery purpose. Alternatively, Job's desire to present the testimony to the Duke can be understood that he wanted to convey the issue of enslavement of such Africans, as the following sections of the account reveal, and his good character and civilized African hometown to a white political leader. Consequently, the Duke could possibly share Job's testimony with his friends and change some existing racial stereotypes concerning Africans and the issue of slavery. Arguably, this might be the same reason for why Job preferred his testimony being written in English even though he was able to write his narrative in Arabic (Notevii); the possibility of his English testimony to be read by Europeans and Americans would be greater than that of his Arabic testimony. Douglas Grant (1968) believes that Francis Moore's account (Noteviii) Travels Into the Inland Parts of Africa (1738) and Bluett's Some Memoirs of Job made Job "a significant figure in the battle against slavery" (p. 143). A further reason for Job's intention in giving the account to the Duke is that he presumably wanted his testimony to be received by a respected political personage at that time. This intention is consistent with stating the purpose of the letter or preface in early slave narratives. What is more, Bluett's positive reflections on Job continue to appear throughout the testimony, for instance Section Four and the Conclusion, also give acknowledgement to Job for contemporary western readers.

The Introduction of the testimony also extends the acknowledgment of Job by referring to him as "this African Gentleman" (as cited in Austin, 1984, p. 77). Besides, it discusses the agreement between Bluett and Job in writing the testimony. Bluett states that they were "agreeable to the Information he [Job] had given me at different Times, and to the Truth of the Facts, which I had either been a Witness to, or personally concerned in upon his Account" (as cited in Austin, 1984, pp.76-77). The purpose of the account is also revealed in the Introduction. Bluett elaborates that the purpose of the testimony, thus:

At least it cannot but be agreeable to those Persons, who were pleased to do kind Offices to this Stranger, merely from a Principle of Humanity, before any particular Account of him could be had. Therefore I have at length resolved to communicate to the World such Particulars of the Life and Character of this African Gentleman, as I think will be most useful and entertaining; intending to advance nothing as Fact, but what I either knew to be such, or have had from JOB's own Mouth (as cited in Austin, 1984, p.77)

Two issues occur here concerning the testimony's purpose and genre. Regarding the purpose, even though Bluett states the entertainment purpose of the testimony, the claim about Job's intention of the account presented by Bluett cannot be justified. In fact, Bluett misunderstood some facts which Job had told him (Noteix). This can suggest that Job told Bluett about the topics and ideas which he wanted to include in the account. Therefore, this narrative can be considered as other later amanuensis slave narratives. Two differences between this account and other amanuensis slave narratives are that this account was written in a third-person narration and the writer's role is obvious more than the roles of ghost writers and editors of other slave narratives.

The second issue that concerns the testimony genre is that while Foster (1994, p. 35) and Al-Ahari (2009, p. 12) believe the account to be a biography, Ronald Judy (1993) claims it is a "reported autobiography'... (which Bluett swears was faithfully recorded from the mouth of Ayyub)" (emphasis in original, p. 154). However, Bluett states in the letter regarding the account that "I am very sensible the imperfections of it are many; but hope our GRACE will pardon them, especially as I have not been us'd to such Matters as these. The Facts I have inserted, are what I had by JOB's particular information, or from my own Knowledge" (as cited in Austin, 1984, p. 75-76). Whether Job's testimony is considered as biography, autobiography, slave narrative, or freedom narrative, the account still can be defined among early slave narratives since there is not a fixed definition of these narratives as has been mentioned above. 
Section One entitled "An Account of the Family of JOB; his Education; and the more remarkable Circumstances of his Life, before he was taken Captive", is the exposition of the narrative. This section starts with a discussion of the establishment of Job's town, Bundu, and its regulations. Bundo was established half a century ago "as a safety zone for every Muslim (all who could "read and know God") fleeing slavery" (Austin, 1997, p. 54). Then, it discusses Job's religious education (Notex) and political and social status in his homeland. The end of this section mentions Job's wives and children. It is strongly suggest in this section, Job and Bluett tried to construct the theme of the noble savage of Job's character through the represented information.

Section Two is the longest among the four sections. This section combines the rising actions, the climax and falling action of the narrative plot as is conveyed from its title, "Of the Manner of his being taken Captive; and what followed upon it, till his Return". Regarding his capture, Job was kidnapped with his interpreter and servant Lomein Ybai by the Mandingos who were his tribe's enemy. A couple of days before his enslavement, Job tried to sell two slaves to Captain Pike, a captain of an English ship, in order to buy paper, but they could not agree on price. He crossed into the Mandingos' land with Lomein Ybai, even though his father had warned him about doing that, and exchanged the slaves for "twenty-eight head of cattle" (Grant, 1968, p. 67). He decided to take a rest and lay down all his weapons. While he was resting, seven or eight Mandingos seized him, Lomein and their weapons. The kidnappers shaved their heads and took all the things that could reveal their high status in order that they appeared as prisoners of war (as cited in Austin, 1984, p.79). Then, the Mandingos sold Job and Lomein to Captain Pike. Job asked Captain Pike to wait for his father's ransom, but the message was very late. His father sent "several" slaves, presumably non-Muslims, as the ransom for his son (as cited in Austin, 1984, p. 79). These events clearly indicate that slavery was a practice in Job's homeland (Notexi). However, it was illegal to enslave Muslims in Bundu as the testimony refers to protect every runaway Muslim (Austin, 1984, p. 78). Also, Austin mentions that travelers noted Muslim Fulbe or Fula, an African ethnic group to which most enslaved African American Muslim narrators and Job belonged, "were prominent in the slave trade-as they were prominent in all trade. But they were not all slavers and they had their codes for the business" (Austin, 1984, p. 27).

The rising actions, as it has mentioned earlier, are also about the narrator's life in slavery and its harshness. In fact, the part of Job's life under slavery in America is short compared to the rest of the account. Austin (1997) comments that “"the slave narrative' section takes up only one and a half pages out of fifty-four" (p. 54). Job arrived in Maryland in 1730, where Tolsey became his master. Job's relationship with his master Tolsey is not explained in detail in Bluett's account (Notexii). Generally, Tolsey appeared to be a kind master to Job (Notexiii). It was never reported that Tolsey had physically abused Job. This is given further weight in that no other authors mention Tolsey's bad treatment of Job; for example Moore states in his account that Job lived with Tolsey for about one year "without being once beat by his master" (as cited in Curtin, 1967, p. 55). Also, when Job complained about the hard work at the tobacco plantation, Bluett states that "his Master was obliged to find easier Work for him" (as cited in Austin, 1984, p. 80); Tolsey subsequently assigned him to work with the cattle. Even though Tolsey had given him alternative work, he was still unhappy with it and he "would often leave the Cattle, and withdraw into the Woods to pray" (as cited in Austin, 1984, p. 80). We should carefully think about this 'kind' treatment whilst he was a slave when we consider his return into the slave trade after he, himself, was freed. It could have been different if he was treated badly. According to Grant (1968), "Tolsey must have been either careless or inexperienced in the managing of slaves to set Job immediately to the heavy work of a tobacco plantation" (p. 79). Similarly, Austin (1984) claims that "Tolsey seems to have pushed Job hard at first, but to have become quite reasonable and resigned later. Had he been informed that the Fulbe usually abhorred physical labor and had a tendency about to malinger in the face of it ... and that the Fulbe loved cattle?" (p. 113). Another possibility is that Tolsey was simply a kind hearted master.

Bluett writes that there are "other Misfortunes" and this comment also adds to the unclear master-slave relationship. One of these misfortunes was the abuse that Job suffered by a white boy while he was praying, which led to him thinking about the idea of running away. However, Bluett does not specify what these "other misfortunes" are, whether they are related to Job's master-slave relationship or to other things. Abdulhafeez Turkistani (1995) believes that Bluett's phrase suggests that "he is inconsistent with his plentiful details of cultural, geographical, and historical information in the rest of the biography" (p. 108). Later, Bluett refers to Job's motivations to escape, saying that "he might possibly be taken up by some Master, who would use him better, or otherwise meet with some lucky Accident, to divert or abate his Grief" (as cited in Austin, 1984, p. 80). So, Job was looking for a kind master. Arguably, Job was applying the Islamic concept of 'hijra', which means a flight from a place, where Muslims receive harsh treatment and cannot practice their Islamic duties, to a better place (Notexiv). Presumably, he thought that there was a place outside Maryland where he could live freely according to the law of Bundo for runaway Muslim slaves. However, Bluett comments that after Job escaped and was jailed, Tolsey "became kinder to him and gave him a place to pray, and some other Conveniences, in order to make his Slavery as easy as possible" (as cited in Austin, 1984, pp. 80-81).

Even though he was given what he had asked for and his master was kind, "yet Slavery and Confinement was by no means agreeable to JOB, who had never been used to it” (as cited in Austin, 1984, p. 81). While he was at Tolsey's plantation, Job wrote a letter in Arabic to his father to redeem him from slavery. Turkistani (1995) believes that enslaved African American Muslims were strong believers and one of the Islamic principles of belief is to submit to one's fate and to be patient and not protest; with respect to Job, Turkistani claims that:

Unlike many other slaves, he ran away not because of physical abuse, but because of psychological abuse. ... This shows that his faith in God and acceptance of his fate did not change. He did not show any sign of resentment or 
anger against his fate. Of course, he tried to change his situation, but not for material gain; his escape was motivated by his religious beliefs and would thus be considered a great deed for a Muslim. (pp. 105-106)

To a certain degree Turkistani's argument about Job's religious motivation to escape is correct. When Job could not practice his Islamic belief, his problem became psychological rather than physical. Al-Ahari also believes that "slavery was a fact of life for him [Job] and a condition he was placed in by the hand of God. He accepted his fate as long as he could practice Islam. He attempted escape when he was harassed while performing his duties to God" (2006, p. 13)

Regarding Job's letter to his father, Gates Jr. (1989) claims that this “one early eighteenth-century slave's experiences represent the relationship between freedom and literacy dramatically and more directly, indeed, than would seem possible" (p. 12). It was intended that it be given to Captain Pike in order that he deliver it to Africa, but he had already left to England. Ironically, by the time the letter was sent to England, Captain Pike had left to Africa. The philanthropist James Oglethorpe, who read this letter in its subsequent English translation, sympathized with Job. Oglethorpe agreed with William Hunt, a merchant, to purchase Job's freedom and when the latter arrived in England, Oglethorpe would pay back Hunt his money. When Job was on his voyage, he started to learn English. He made a significant progress in acquiring the language. His ability to learn English language also can be considered as an element of the noble savage trope. However, his illness hindered the progress. When Job arrived in England, Oglethorpe had left to America. Job was worried that Hunt might sell him into slavery. The Royal African Company reimbursed Hunt for redeeming Job out of slavery and taking Job to England. However, Job did not feel he was a free person yet.

The climax is when Job became a free person. Bluett with the help of his friends and gentlemen who met Job paid the sum of money to the Royal African Company. The falling actions of early slave narratives, as Foster (1994) claims, are "the spiritual or material reward" (p. 45). Here in Job's testimony, the falling actions are his material reward in meeting English noblemen and his return to Africa. He was given a golden watch as well as tools and machines which could improve the standard living of Job's society. These gifts were estimated via 500 pounds sterling. Arguably, therefore, the material reward for Job is more than the spiritual reward. Job appears to be a strong believer throughout the testimony. He continues to practice his Islamic duties while he was enslaved. This suggests that Job did not have a spiritual development. However from a religious perspective, the material reward can also be considered as providence.

Although Section Two seems to be the end of the slave narrative, Job and Bluett continue to write two more sections and a conclusion. These sections are important in emphasizing the idea of the noble savage and the conclusion conveys an anti-racist position via a religious perspective. In Section Three "Some Observations, as related by JOB, concerning the Manners and Opinions of his Countrymen", Bluett writes about subjects of marriage, burial, hunting, courage and religious beliefs of Job's homeland. This section appears to be more to entertain and inform the reader as Bluett states as the purpose of the testimony in the letter. More than for the purpose of entertainment, these topics of courage and religious identity, in particular, are supportive elements in constructing the theme of the noble savage.

The theme clearly continues in Section Four, “Of JOB's Person and Character”, through its listing of Job's physical, intellectual and religious characteristics. Regarding his physical features, they are presented as "being very different from that of the Negroes commonly brought from Africa" (as cited in Austin, 1984, p. 88). This statement implies a pro-slavery position for not criticizing the institution of slavery. It, however, just merely suggests indirectly that the enslavement of such Africans as Job is an unfair act. Intellectually, Job was an educated man, depended on reasoning in his judgment, and had a retentive memory; he wrote down three copies of the Holy Quran from memory. Even though Job did not master the English language, local people who met where able to understand him when he conversed with them. In terms of belief, Job was a devout follower of a monotheistic faith. He was equally knowledgeable about Christianity and its association with Islam through their common prophets and their messages. Austin claims that enslaved Muslims had a profound education and faith, and because of their monotheistic religion and their literacy, some Western intellectuals and thinkers described these Muslims as Arabs rather than Africans, "Negros" (1997, p. 13). Clearly, the testimony reflects that Job is different from non-Muslim Africans in terms of his religion and literacy. Another indication of distinction between Job and other non-Muslim Africans, is his practice in selling enslaved people before his enslavement. As Grant (1967) observes, Job appears as a "sympathetic", yet "paradoxical" character for practicing slavery (p. 144). In sum, Curtin (1967) remarks that idea of the noble savage in Job's testimony "in outline has the classic elements of many later works" (p. 17).

The Conclusion, "Containing Some Reflections upon the whole", comes as a critique against eighteenth-century racial philosophies from a religious perspective (Notexv). Bluett writes that God is the One who wisely governs the world, whereas human beings altogether are not able to understand the wisdom of God and the "secret Springs of Nature". Therefore, the slave trade was a human invention and practitioners of it believed that would benefit the world, but it did not. Even though the account does not carry a direct anti-slavery theme attitudes toward morality were influenced by their religious beliefs, both were religious men. Also, the Conclusion emphasizes the fact that Job had a religious perspective regarding his enslavement, similar to the perspective of early slave narratives. Job was influenced by religious stories in which he "frequently compared himself to Joseph, believing that it was not the Mandingoes, but God "who brought him into a strange Land" (as cited in Austin, 1984, 92). This can be related to the Judeo-Christian belief of redemption from slavery which was also a characteristic of early slave narrative. In addition, the account indicates that many Africans had religions and education and not as contemporary racial philosophies aimed to justify slavery. Arguably, Bluett and Job may consider giving this religious topic against racial theories as the last impression or 
message to the reader. Generally, the analysis reveals that the plot and characteristics of testimony are similar to the characteristics of early slave narratives.

\section{Conclusion: Positioning Job's Testimony}

The questions of authorship and identity of Some Memoirs of the Life of Job have led to arguments that range between positioning it as the pioneer slave narrative and excluding it from anthologies African American literature. The characteristics and traditions of the testimony share similarities with the conventions of eighteenth and nineteenthcentury slave narratives. In alignment within this, Austin believes the testimony might provide "a conceptual model, in the part at least, for overlooked aspects of later African and African American memoirs or narratives" (1997, p. 59). The idea of the noble savage is clearly presented in the testimony; Job's social status in the title of the account as "the High Priest of Boonda in Africa" and his refine manners and positive characteristics throughout the account. The testimony indicates that Africans are humans, civilized, have the ability to read and write, and many if not all, believe in religions (Notexvi). These are evidence which falsify contemporary colonial racial stereotypes about Africans. Also, the testimony highlights the importance of education which an important theme in early and antebellum slave narratives. The theme of seeking for freedom, which is a significant trope in the nineteenth-century slave narrative, appears in Job's testimony although it is limited to an individual interest and Muslim community in particular. Besides the clear religious perspective of the testimony, it attempts to deal with a political aspect though presenting the account which conveys such a civilized African to a European leader which may lead to a political change in view on slavery. Therefore, the testimony combines two perspectives of early and antebellum slave narrative, the religious and political perspectives.

These characteristics support the inclusion of Some Memoirs of the Life of Job in American literature since it has elements and traditions of early and antebellum slave narratives. Job's testimony can be included in American literature as part of colonial American literary history. Besides, it provides how form and themes had evolved in the slave narrative a genre (Notexvii). The testimony draws attention to using Biblical and Quranic stories in slave narratives which could suggest some similarities between the narratives of enslaved African American Muslims and the slave narrative genre. Therefore, these concerns can widen the definition of the genre of slave narrative.

\section{Acknowledgements}

I would like to thank Dr. Doris Hambuch, my research supervisor, for her useful comments and suggestions on the paper.

\section{Sponsoring information}

The Research Council and Al Buraimi University College, the Sultanate of Oman.

\section{References}

Afroz, S. (2000). Islam and Slavery Through the Ages: Slave Sultans and Slave Mujahids. Journal of Islamic Law \& Culture, 5(2), 79-123.

Ahari, M. (Ed.). (2006). Five classic Muslim slave narratives. Chicago: Magribine Press.

Aljoe, N. (2014). Introduction. In N. Aljoe \& I. Finseth (Eds.), Journeys of the slave narrative in the early Americas (pp. 1-15). Charlottesville: University of Virginia.

Andrews, W. (1988). To tell a free story: The first century of Afro-American autobiography, 1760-1865. Urbana: University of Illinois Press.

Austin, A. (Ed.). (1984). African Muslims in antebellum America: A sourcebook. New York: Garland.

Austin, A. (1997). African Muslims in antebellum America: Transatlantic stories and spiritual struggles. New York: Routledge.

Bland, S. (2001). Introduction: Bearing Witness: The Fugitive Slave Narrative and Its Traditions. In S. Bland (Ed.), African American slave narratives an anthology. (Vol. 1 pp. 1-22). Westport: Greenwood Press.

Carretta, V. (2010). Back to the Future: Eighteenth-Century Transatlantic Black Authors. In G. Jarrett (Ed.), $A$ companion to African American literature (pp.11-24). Chichester: Wiley-Blackwell.

Curtin, P. (1967). Africa remembered; narratives by West Africans from the era of the slave trade. Madison: University of Wisconsin Press.

Dabovic, Safet, (2009). Displacement and the negotiation of an American identity in African Muslim slave narratives. (Doctoral dissertation). Retrieved from ProQuest Dissertations \& Theses Global. (Order No. 3401700).

Foster, F. (1994). Witnessing slavery: The development of ante-bellum slave narratives (2nd ed.). Madison: University of Wisconsin.

Gates, H. (1989). Figures in black: Words, signs, and the "racial" self. New York: Oxford University Press. 
Grant, D. (1968). The Fortunate slave: An illustration of African slavery in the early eighteenth century. London: Oxford University Press.

Green, K. (2014). Uncommon Sufferings: Rethinking Bondage in A Narrative of the Uncommon, and Surprizing Deliverance of Briton Hammon, a Negro Man. In N. Aljoe \& I. Finseth (Eds.), Journeys of the slave narrative in the early Americas (pp. 101-126). Charlottesville: University of Virginia.

Gronniosaw, J. (2000). A Narrative of the Most Remarkable Particulars in the Life of James Albert Ukawsaw Gronniosaw, an African Prince, as Related by Himself. In W. Andrews \& H. Gates Jr. (Eds.), Slave narratives (2nd ed., pp. 1-34). New York: Literary of America.

Horn, P. (2012). Coercions, Conversions, Subversions: The Nineteenth-Century Slave Narratives of Omar ibn Said, Mahommah Gardo Baquaqua, and Nicholas Said. Auto/Biography Studies, 27(1), 45-66.

Judy, R. (1993). (Dis)forming the American canon: African-Arabic slave narratives and the vernacular. Minneapolis: University of Minnesota Press.

Lepore, J. (2002). A is for American: Letters and other characters in the newly United States. New York: Alfred A. Knopf.

Lovejoy, P. (2011). 'Freedom Narratives' of Transatlantic Slavery. Slavery \& Abolition, 32(1), 91-107.

Marfo, F. (2009). African Muslims in African American Literature. Callaloo, 32(4), 1213-1222.

Sollors, W. (2000). Introduction. In M. Shell \& W. Sollors (Eds.), The Multilingual anthology of American literature: A reader of original texts with English translations. New York: New York University Press.

Sollors, W. (2001). Introduction. In The interesting narrative of the life of Olaudah Equiano, or Gustavus Vassa, the African (pp. ix-xxxi). New York: Norton.

Starling, M. (1981). The Slave narrative: Its place in American history. Boston: G.K. Hall and Co.

Turkistani, A. (1995). Muslim slaves and their narratives: Religious faith and cultural accommodation. (Doctoral dissertation). Retrieved from ProQuest Dissertations \& Theses Global. (Order No. 9604469).

\section{Notes}

Note i. Thomas Bluett was an Englishman who met Job when the latter was imprisoned in Maryland. According to Austin (1984), Bluett was a minister in Maryland. Job sailed to England with Bluett.

Note ii. Jill Lepore (2002) claims Abdr-Rahman, an enslaved African Muslim, unlike Fredrick Douglass, did not show interest in being American (p. 126). However, Sollors (2000) states that Omar ibn Said, another enslaved African Muslim, was "as American as Frederick Douglass" (p. 5).

Note iii. This argument is also mentioned by Patrick Horn in the notes to his article "Coercions, Conversions, Subversions: The Nineteenth-Century Slave Narratives of Omar Ibn Said, Mahommah Gordo Baquaqua, and Nicholas Said" (2012, p. 62).

Note iv. Foster only discusses the account of Job ben Solomon on (pp. 33-36, 42, 46-47).

Note v. Even though that religion was used to defend and justify slavery by pro-slavery supporters.

Note vi. Some words in Job's account are capitalized as in the original source. Here, I used Job's account which appears in Austin's Sourcebook (1984).

Note vii. Job was educated in Arabic before his enslavement. In the discussion of Job's education, Curtin (1967) claims that " $[\mathrm{t}] \mathrm{h}$ le level of his knowledge of Arabic also points to the kind of education that might be expected of a diula, or travelling merchant, rather than of an important Islamic scholar" (p. 26). He adds that his letters in Arabic suggest that he was "neither familiar with spoken Arabic nor grounded in classical written Arabic" (p. 26). Contrary to this claim, Job was educated to officiate as an imam. As the testimony states, "[w]hen Job was fifteen Years old, he assisted his Father as Emam, or Sub-priest” (as cited in Austin, 1984, p. 78). See also (Turkistani, 1995, p. 103).

Note viii. Francis Moore was an English factor of the Royal African Company. His account reveals information about Job after his return to Africa.

Note ix. For example, Bluett states in the account that revelation of the Holy Quran to "Ababuker, some time before Muhammad was born" (as cited in Austin, 1984, 90), which is false. In addition, Curtin comments that "[ $t]$ he conflict between tradition and Ayuba's account immediately raises the question whether he was lying, or whether Bluett simply misunderstood him" $(1967,27)$. Bluett confesses his weakness in presenting information:

I Don't pretend here, as I hinted before, to trouble the Reader or myself with a full and regular History of JOB's Country. Those who have the Curiosity to inform themselves more particularly in the History of those Parts of the World, may consult the Voyages that are already published on that Subject" (as cited in Austin, 1984, p. 84).

See also (Dabovic, 2009, p. 24) and (Grant, 1968, p. 143).

Note x. Unlike enslaved African American narrators, education had already been gained by enslaved African American Muslims before their enslavement. Mostly, however, they were not able to write in English, such as Omar, Abdr- 
Rahman and Job. African American slave narrators, such as Abdr-Rahman, Omar and Abu Baker, refer to their education at the beginning of their narratives. For example, Abu Baker presents his educational background and names of some scholars even before he gives details of his family. This is because he mentions he was born in, which at that time was considered as a seat of learning in West Africa.

Note xi. Enslaved people were a recognized social class in Bundu. For instance, in Section Three, Bluett writes "In JOB Country the Slaves, and poorer sort of People ..." (as cited in Austin, 1997, p. 84).

Note xii. See also (Turkistani, 1995, p. 108).

Note xiii. Tolsey appeared similar to Omar's master, Owen, in his kindness. However, Omar agreed to stay with Owen unlike Job.

Note xiv. Omar also conveys the hijra trope when he fled from his master. Afroz (2000) discusses the idea of hijra which was applied by many enslaved Muslims in America: "a common resistance to the slave system was the hijra/ flight from servitude to establish their own ummah/ communities based on consensual leadership (shura) and Islamic tradition and culture in inhospitable and inaccessible areas throughout the Americas" (p. 118).

Note xv. See also (Austin, 1997, pp. 58-59).

Note xvi. See also Austin (Austin, 1997, p.59).

Note xvii. The co-editor of Journeys of the Slave Narrative in the Early Americas, Nicole Aljoe (2014), discusses similar arguments of the importance of inclusion of different early slave narratives. 